\title{
TÁMOGATÓ RENDSZEREK, SZOCIÁLIS PROBLÉMÁK ÉS SEGÉLYEZÉS
}

\author{
BALOGH ERZSÉBET - FÁBIÁN GERGELY
}

\begin{abstract}
Absract: Support system, social problems and social tansfer. The aims of the study the natural supporter system, the social services, information views and opinions conserning the social benefit. Not only presenting the existence of the supporting systems, but also types of problem with which people turn to for help. We go into details about the types of social assistance and its efficiency. We examined how the general opinion on social benefit developed from the benefit. We reviewed them separately from the 2008 and the 2010 database.
\end{abstract}

Keywords: natural, artificial supporting systems, social transfer, disadvantag-ed groups

DOI: $10.19055 / \mathrm{ams} .2012 .3 / 3 / 9$

Kivonat: A tanulmány része a „Életminőség Nyíregyházán 2008-2010” vizsgálatból készült elemzésnek, célja a természetes támogatórendszerek, a szociális szolgáltatások, illetve a segélyezésre vonatkozó információk, nézetek, vélemények felmérése.

Elemzésünket a természetes támogató rendszerek meglétének vizsgálatával kezdjük, bemutatva nemcsak a támogató rendszerek meglétét, hanem azokat a problématípusokat is, amelyekkel ezekhez a rendszerekhez fordulnak segítségért. A természetes védőhálók megnövekedett szerepének keretében nőtt a szociális osztályhoz fordulók száma is, amely indokolta annak vizsgálatát, hogy melyek azok a segélyezési típusok amelyek segítséget nyújthatnak a problémáik megoldásában, illetve hogy hogyan vélekednek az azokat igénylők azok hatékonyságáról, honnan szerzik értesüléseiket a különböző segélytípusokról, mik lehetnek azok az okok amelyek miatt esetleg az arra rászorulók nem veszik igénybe a segélyezést, továbbá kíváncsiak voltunk arra, hogy hogyan alakítanák át a nyíregyháziak a segélyezésre való jogosultság feltételeit.

A tanulmány következő nagy blokkjában azt vizsgáltuk, hogy hogyan alakultak a vélemények általában a segélyezésről. A vélemények sajátos kettőssége indokolta, hogy faktorelemzéssel is megvizsgáltuk a kapott eredményeket, annak érdekében, 
hogy lássuk, hogyan csoportosíthatóak az egyes vélekedések. Külön tekintettük át a 2008-as és a 2010-es véleményeket az adott kérdéssel kapcsolatban. Ezt követően a pénzbeli és természetbeni ellátásokban részesültek arányát mutatjuk be.

Kulcsszavak: természetes, mesterséges támogató rendszerek, szociális segélyezés

\section{TÁMOGATÓ RENDSZEREK}

A természetes támogatórendszerek, a szociális szolgáltatások, illetve a segélyezésre vonatkozó információk, nézetek, vélemények feltárását elsőként annak vizsgálatával kezdtük, hogy a megkérdezettek kinek a segítségére számíthatnak szociális problémáik megoldásában. (1. ábra)

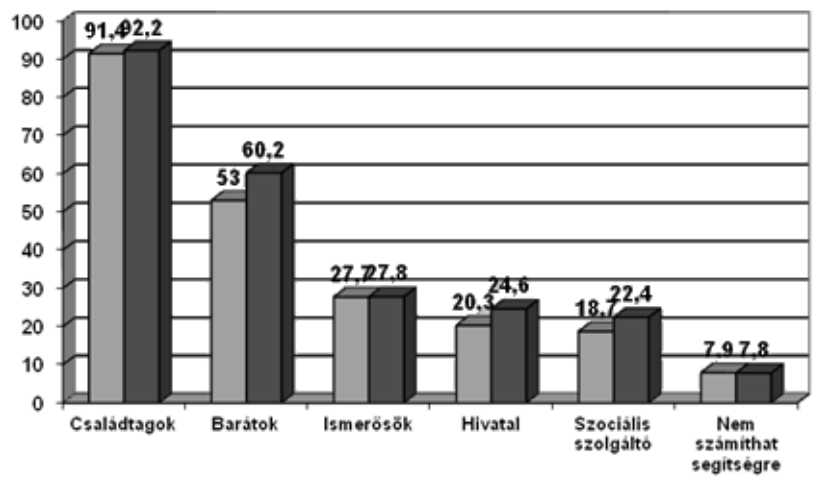

$\mathbf{0 2 0 0 8} \mathbf{\square 2 0 1 0}$

1. ábra - Szociális problémájának megoldásában kinek a segítségére számíthat az igen válaszok aránya, 2008-2010. Forrás: saját adatfelvétel.

Az adatokból jól látható, hogy a városlakók elsődlegesen a család segítségét veszik igénybe szociális problémák esetében, csak ezután következnek a barátok, ismerősök, illetve a mesterséges védőháló elemei, azaz az önkormányzat, illetve az egyes szociális szolgáltatók, bár arányuk közel sem elhanyagolható. Relatíve kevesen nyilatkoztak úgy, hogy egyáltalán nem számíthatnak segítségre. A változás a gazdasági válság egyik jól mérhető hatása, hiszen több esetben növekvő értékek mutatkoznak. Kiemelendő, hogy nemcsak a természetes védőháló esetében (barátok) látható növekedés, hanem a polgármesteri hivatal, illetve a szociális szolgáltatók esetében is, mindkét esetben 4 százalékponttal nőtt a „bizalom”, vagy legalábbis az a remény, hogy a mesterséges védőháló szereplői is tudnak segíteni a problémák megoldásában. A természetes védőháló esetében az esetek jelentős részében az emberek mentális jellegü segítségben részesül- 
nek (2008: 67 \%; 2010: 65,6 \%), ezt követi a természetbeni segítség (2008: $61 \%$; 2010: 61,4\%)), illetve a pénzbeli segítség (2008: $49 \%$; 2010: 56,8 \%). Növekedés egyedül a pénzbeli segítségnél mérhető, ami szintén jelzi a gazdasági válság hatását. A természetes védőháló szerepét ettől részletesebben vizsgálta kötetünkben Huszti Éva, Társas kapcsolatok - Családi, rokoni, baráti kapcsolatok Nyíregyháza lakói körében c. tanulmányában.

A Szociális Osztályhoz 2008-ban a városlakók 17 százaléka fordult szociális problémájának megoldása érdekében, 2010-ben 15 százaléka. A kérelmezők az esetek egy igen jelentős részében pénzbeli támogatásban részesültek (arányuk 2008-ban $68 \%$, míg 2010ben 80,8\%), természetbeni támogatást kapott 2008-ban 21.4\%, 2010-ben $17 \%$, felvilágosításban, tanácsban részesült több mint harmaduk (39,6\% mindkét adatfelvételnél), más intézményhez pedig 13,5, illetve 2010-ben 11,1 százalékukat irányították. Az osztályhoz fordulók körében 2008-ban 39,4 százalék volt azok aránya, akik az elmúlt két évben (2006 és 2007 során) kértek segélyt, mint támogatást, ez az arány 2010-ben is jellemző volt. A segély összegének átlaga 18.000 és 19.000 forint közé esik, ez valamivel alacsonyabb 2010-ben, de jelentős mértékü változás nem mérhető. A kérelmezők az elmúlt két évben átlagosan és a leggyakrabban 2-3 alkalommal fordultak az osztályhoz ilyen kéréssel, ugyanakkor vannak, ugyanakkor vannak természetesen olyan ügyfelek is, akik jóval több alkalommal kértek segélyt (nem ritka a 10-nél magasabb érték). A kérelmezők általában a pénzbeli támogatási formákat preferálják -2. ábra.

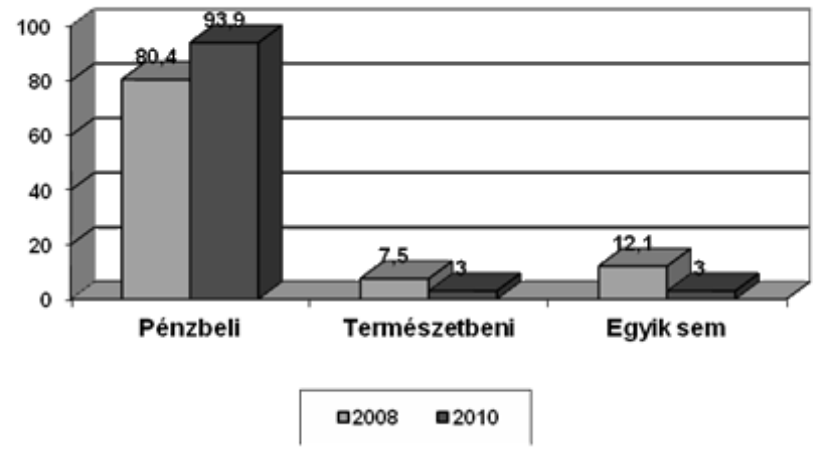

2. ábra - Milyen segélyezési forma nyújt megoldást a problémájára, 2008-2010 (\%). Forrás: saját adatfelvétel.

A segélyben részesülteknek egyre növekvő része véli úgy, hogy a pénzbeli támogatás jelenthet megoldást problémájára. csak egy kis része vélekedik úgy, hogy a támogatás teljes mértékben megoldotta a problémáját, úgy látják, hogy a segély csak részleges megoldási lehetöségként müködik. (3. ábra)

Bár enyhe növekedés látható a teljes mértékben, és csökkenés az egyáltalán nem válaszoknál, a döntő többség számára a kapott támogatás csak részleges megoldást jelent. 
A segély igénybevételének lehetőségéről a legtöbben ismerősöktől szereztek tudomást, egyre növekvő arányban, de relatíve magasnak tekinthető azoknak az aránya is, akik a helyi médiákból tájékozódtak. (4. ábra)

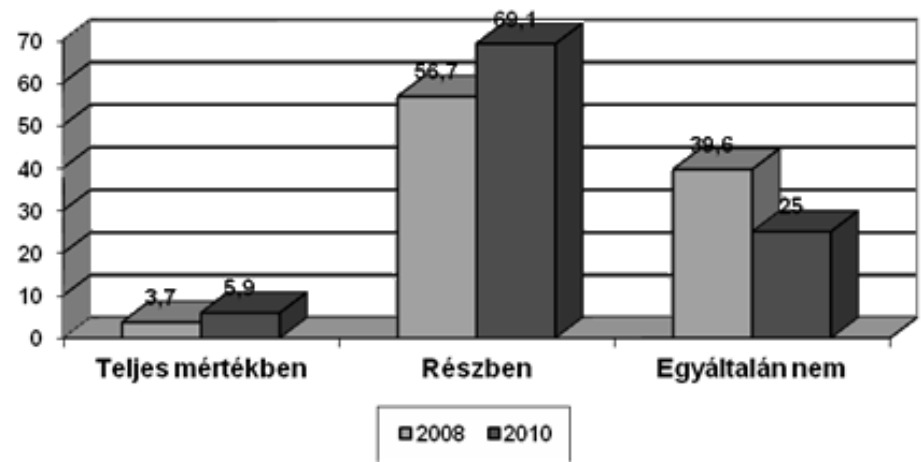

3. ábra - A megállapított segély megoldotta-e problémáját, 2008-2010 (\%). Forrás: saját adatfelvétel.

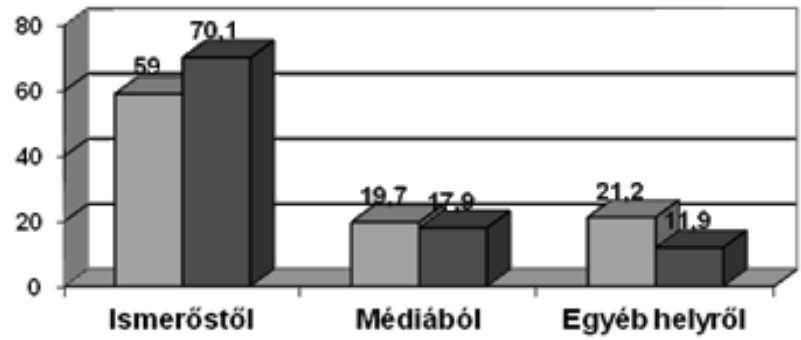

\section{$\square 2008 \square 2010$}

4. ábra - Honnan értesült a segély igénybevételének lehetőségéről (\%). Forrás: saját adatfelvétel.

Akik nem részesültek az elmúlt két évben segélyben, azok körében a legmagasabb arányban azokkal találkozhatunk, akiknek a kérelmét elutasították (2008: 36,1 \%, 2010: 33,3 $\%$ ), illetve úgy vélik, hogy nem lennének jogosultak rá (2008: 29,6\%; 2010: 32,1\%). A segélykérelmek elutasításának döntő oka a jövedelemben rejlik. (5. ábra)

A nyíregyháziak harmada véli úgy (mindkét adatfelvétel esetében), hogy ismer szükebb környezetében olyanokat, akik jogosultak lennének segélyre, de nem veszik igénybe azt. Abban a tekintetben, hogy vajon ezek az emberek miért nem élnek ezzel a lehetőséggel, megoszlanak a vélemények. Bár vannak különbségek, lényeges eltérések nem igazán figyelhetők meg az elmúlt időszakban. (6. ábra) 


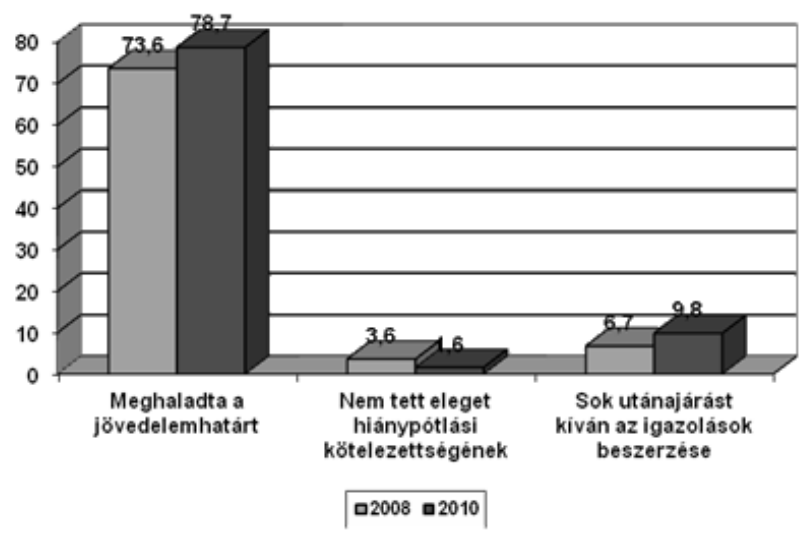

5. ábra - A segély iránti kérelem elutasításának oka (\%). Forrás: saját adatfelvétel.

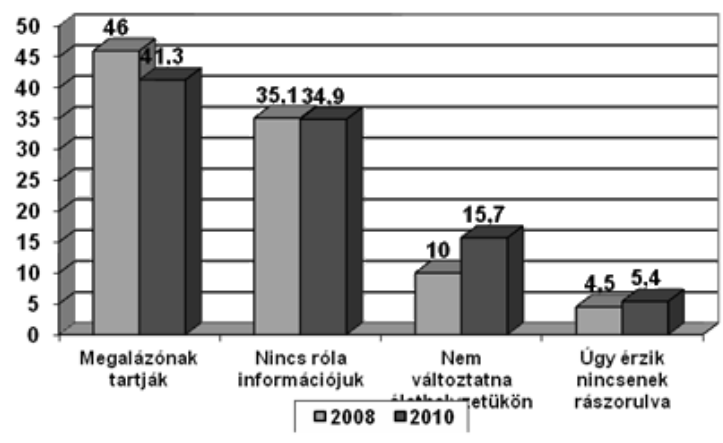

6. ábra - Megítélése szerint miért nem veszik igénybe a segélyezést azok, akik jogosultak lennének rá, 2008-2010 (\%). Forrás: saját adatfelvétel.

Mivel a segélyezéssel kapcsolatos kérdések már 2008-ban társadalmi viták kereszttüzében álltak, érdekes kérdés, hogy a nyíregyháziak hogyan változtatnának a segélyre való jogosultság feltételein. (7. ábra)

Jelentős változás nem figyelhető meg az elmúlt időszakban, továbbra is domináns a probléma jellegének, nagyságának a megítélése, illetve a családi kiadások figyelembe vétele. Enyhén csökkent a jövedelemhatár emelésének említése, illetve kis mérték ben növekedett a nagycsaládosok és az egyedülállók előnyben részesítése. 


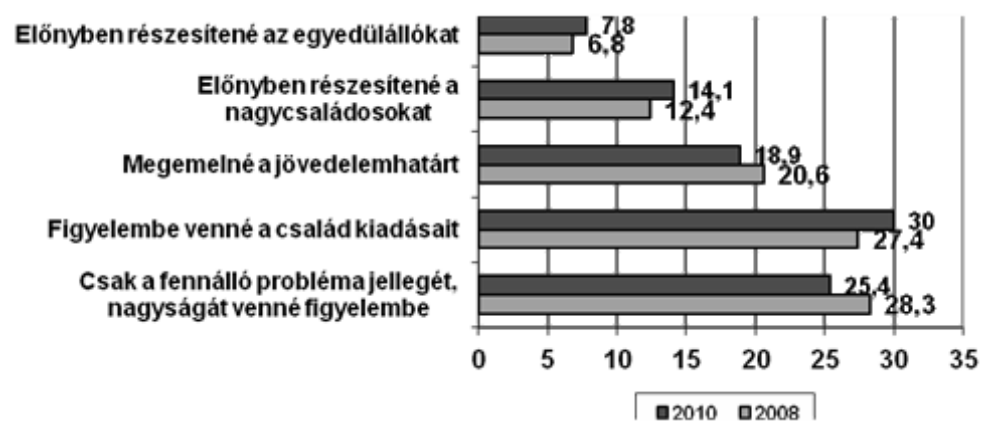

7. ábra - Hogyan változtatná meg a segélyre való jogosultság feltételeit, 2008-2010 (\%). Forrás: saját adatfelvétel.

\section{SEGÉLYEZÉSSEL KAPCSOLATOS VÉLEMÉNYEK}

A segélyezéssel kapcsolatos általános véleményeket több kijelentéssel teszteltük a kutatásban. A megkérdezettek minden kijelentés esetében egy öt fokozatú Likert skálán nyilváníthatták ki véleményüket, mennyire értenek egyet, vagy utasítják el az adott kijelentést. Az eredményeket 100 fokú skálára transzformálva mutatjuk be. (1. táblázat)

Sajátos kettősség figyelhető meg a véleményekben. Miközben a nyíregyháziak maximálisan elutasítják azt, hogy a segélyezés nem szükséges, azaz „meg kellene szüntetni”, vagy fel kellene számolni (ez a legelutasítottabb kijelentés), illetve egyetértenek azzal, hogy szükség van rá, mert bizonyos problémákat csak ezáltal lehet megoldani, addig azzal is egyetértenek, hogy vannak „csalók” a rendszerben, akik kihasználják azt, mert eltagadják jövedelmi helyzetüket, illetve igénybe veszik, miközben nincsenek rászorulva.

A két adatfelvétel átlagai közel vannak egymáshoz, néhány esetben azonban már csökkenés figyelhető meg, illetve egy esetben markáns véleményváltozás mérhetö: „,csak azok részesülnek segélyben, akik bevallják valós anyagi helyzetüket”.

A véleményeknek ez a sajátos kettőssége indokolta, hogy faktorelemzéssel is megvizsgáljuk a kapott eredményeket, annak érdekében, hogy lássuk, hogyan csoportosíthatóak az egyes vélekedések. Érdemes elsőként a 2008-ra jellemző eredményeket áttekinteni.

Az elemzést főkomponens analízissel végeztük, melynek során 4 faktor különült el, a megmagyarázott hányad $64,2 \%$. (2. táblázat)

Az első véleménycsoport szerint a segélyezés egy szükséges támogatási forma, ők még gyakrabban is adnának ilyen támogatást, és maximálisan elutasítják azt, hogy ne legyen segélyezés. 


\begin{tabular}{|l|c|c|}
\hline Kijelentések & Átlagérték 2008 & Átlagérték 2010 \\
\hline $\begin{array}{l}\text { Sokan elhallgatják valós anyagi helyzetüket, a segély } \\
\text { megállapítása érdekében }\end{array}$ & 77.1 & 75.1 \\
\hline $\begin{array}{l}\text { Szükséges a segélyezés, mert bizonyos problémákat } \\
\text { csak ezáltal lehet megoldani }\end{array}$ & 71.4 & 58.2 \\
\hline $\begin{array}{l}\text { A segélyeket többnyire azok veszik igénybe, akik nin- } \\
\text { csenek rászorulva }\end{array}$ & 59.2 & 57.0 \\
\hline Inkább természetbeni segélyekre lenne szükség & 54.7 & 51.9 \\
\hline Inkább pénzbeli segélyekre lenne szükség & 53.5 & 31.4 \\
\hline $\begin{array}{l}\text { Csak azok részesülnek segélyben, akik bevallják valós } \\
\text { anyagi helyzetüket }\end{array}$ & 50.4 & 47.2 \\
\hline $\begin{array}{l}\text { A segélyeket azok veszik igénybe, akik valóban rászo- } \\
\text { rulnak }\end{array}$ & 46.2 & 47.1 \\
\hline Gyakrabban kellene, kisebb összegú segélyeket adni & 46.2 & 42.2 \\
\hline $\begin{array}{l}\text { Ritkábban, de nagyobb összegű segélyekre lenne szük- } \\
\text { ség }\end{array}$ & 45.7 & 28.3 \\
\hline Nincs szükség segélyezésre, mert nem nyújt megoldást & 28.4 & \\
\hline
\end{tabular}

1. táblázat - A segélyezéssel kapcsolatos vélemények, 2008-2010 (100 fokú skála átlagértékei). Forrás: saját adatfelvétel.

\begin{tabular}{|c|c|c|c|}
\hline A segélypártiság & $\begin{array}{c}\text { A csalók, mint } \\
\text { a rendszer kihasználói }\end{array}$ & $\begin{array}{l}\text { Természetbeni } \\
\text { támogatás }\end{array}$ & A rászorultak \\
\hline $\begin{array}{l}\text { Szükséges a segélye- } \\
\text { zés, mert bizonyos } \\
\text { problémákat csak ez- } \\
\text { által lehet megoldani } \\
(0.733) \\
\text { Gyakrabban kellene, } \\
\text { kisebb összegű segé- } \\
\text { lyeket adni ( } 0.708) \\
\text { Nincs szükség segé- } \\
\text { lyezésre, mert nem } \\
\text { nyújt megoldást } \\
(-0.685)\end{array}$ & $\begin{array}{l}\text { A segélyeket } \\
\text { többnyire azok veszik } \\
\text { igénybe, akik } \\
\text { nincsenek rászorulva } \\
(0.801) \\
\text { Sokan elhallgatják va- } \\
\text { lós anyagi helyzetü- } \\
\text { ket, a segély megálla- } \\
\text { pítása érdekében } \\
(0.752) \\
\text { A segélyeket azok ve- } \\
\text { szik igénybe, akik va- } \\
\text { lóban rászorulnak } \\
(-0.379)\end{array}$ & $\begin{array}{l}\text { Inkább természetbeni } \\
\text { segélyekre lenne } \\
\text { szükség } \\
(0.843) \\
\text { Inkább pénzbeli segé- } \\
\text { lyekre lenne szükség } \\
(-0.693)\end{array}$ & $\begin{array}{l}\text { Csak azok részesülnek } \\
\text { segélyben, akik } \\
\text { bevallják valós anyagi } \\
\text { helyzetüket } \\
(0.722) \\
\text { Ritkábban, de na- } \\
\text { gyobb összegü segé- } \\
\text { lyekre lenne szükség } \\
(0.641) \\
\text { A segélyeket azok ve- } \\
\text { szik igénybe, akik va- } \\
\text { lóban rászorulnak } \\
(0.600)\end{array}$ \\
\hline
\end{tabular}

2. táblázat - A segélyezéssel kapcsolatos vélemények fökomponensei, 2008 (rotált faktormátrixok). Forrás: saját adatfelvétel. 
A második vélemény szerint a rendszert a csalók használják ki, egyetértenek azokkal az állításokkal, melyek szerint nem az igazán rászorulók részesülnek ebben a támogatásban, illetve logikus módon elutasítják azt, hogy csak a valóban rászorulók kapnának segélyeket.

Külön csoportot képez az a markáns vélemény, mely szerint nincs szükség pénzbeli támogatásokra, hasznosabbak lennének a természetbeni segélyek.

A negyedik vélemény szerint az a reális helyzet, hogy csak a valóban rászorulók részesülnek segélyekben, akik be is vallják valós anyagi helyzetüket. Ezekben az esetekben a ritkábban adott, de nagyobb összegü segélyek kiosztását preferálják a vélemény támogatói.

Érdemes azt is áttekinteni, hogy az egyes véleményeket mely demográfiai - társadalmi csoportok preferálják, illetve utasítják el. ${ }^{1}$

Az első faktor (segélypártiak) esetében az alábbi eredmények jellemzőek (3. táblázat).

A „segélypártisággal” kapcsolatos véleménycsokrot vizsgálva a végzettség tekintetében megállapítható, hogy elsődlegesen az alapfokú végzettséggel rendelkezők preferálják, a felsőfokú végzettséggel rendelkezők körében enyhe elutasításban részesül. Az átlagok alapján jól látható, hogy a legkedvezőtlenebb helyzetü csoportok ha tetszik a legszegényebbek, szinte teljes mértékben ,segélypártiak”, velük ellentétben részben a közepes jövedelmüek (a 7. decilis kivételével), részben pedig a legkedvezőbb helyzetü csoportok elutasítják az adott faktort, azaz nem támogatják a segélyezést, általában nem értenek egyet annak szükségességével.

Ezt az eredményt erősíti meg, ha az átlagokat az egyes "társadalmi rétegek függvényében vizsgáljuk. A kevésbé tehetős társadalmi csoportok általában támogatják a segélyezést, a legkedvezőbb helyzetűek azonban elutasítják az adott főkomponenst. Szignifikáns eltérés mérhető a nemek tekintetében is, a nők általában támogatják az adott faktort, míg a férfiak inkább elutasítóak, aminek magyarázata lehet a nők alacsonyabb foglalkoztatási rátája. A gazdasági aktivitás jellemzőit lásd ebben a kötetben R. Fedor Anita tanulmányában.

Hasonlóan szignifikáns eltérés figyelhető meg az egyes városkörzetek tekintetében is. A különböző városkörzetek mutatóival kötetünkben Malakucziné Póka Mária tanulmánya foglalkozik. A város egyfajta „kettéosztottsága” figyelhető meg, a legkedvezőbb helyzetü körzetekben élők (akik nem igazán tekinthetők pl. a Szociális Osztály ügyfeleinek) általában nem támogatják a segélyezést, azaz nem mondhatók ,segélypártiaknak", a kedvezőtlenebb városkörzetekben élők (akik körében jóval magasabb azok aránya, akik a szociális problémájuk megoldása érdekében már kapcsolatba kerültek az Osztállyal) pedig preferálják az adott faktort. (4. táblázat)

1 Az elemzésben a fökomponensek-score átlagait vettük figyelembe a különböző csoportok esetében. Csak azokat az eredményeket mutatjuk be, amelyek szignifikáns eltérést mutattak. 


\begin{tabular}{|c|c|c|}
\hline \multicolumn{3}{|c|}{ A „segélypártiság” átlagai az egyes végzettségek tekintetében } \\
\hline Alapfokú & 0.27 & $\mathrm{~F}=14.103 ; \mathrm{P}<0.001$ \\
\hline Középfokú & 0.01 & \\
\hline Felsőfokú & -0.18 & \\
\hline \multicolumn{3}{|c|}{ A „segélypártiság” átlagai az egyes jövedelmi decilisek esetében } \\
\hline 1 decilis & 0.32 & $\mathrm{~F}=4.462 ; \mathrm{P}<0.001$ \\
\hline 2 decilis & 0.20 & \\
\hline 3 decilis & 0.29 & \\
\hline 4 decilis & -0.06 & \\
\hline 5 decilis & -0.01 & \\
\hline 6 decilis & -0.01 & \\
\hline 7 decilis & 0.13 & \\
\hline 8 decilis & -0.02 & \\
\hline 9 decilis & -0.19 & \\
\hline 10 decilis & -0.23 & \\
\hline \multicolumn{3}{|c|}{ A „segélypártiság” átlagai az egyes társadalmi csoportok esetében } \\
\hline Szegények & 0.31 & $\mathrm{~F}=6.857 ; \mathrm{P}<0.001$ \\
\hline Alsó középréteg & 0.14 & \\
\hline Középréteg & 0.03 & \\
\hline Felső középréteg & -0.13 & \\
\hline Jómódúak & -0.24 & \\
\hline \multicolumn{3}{|c|}{ A „segélypártiság” átlagai az egyes városkörzetekben } \\
\hline Ókistelekiszőlő & 0.59 & $\mathrm{~F}=2.869 ; \mathrm{P}<0.001$ \\
\hline Huszártelep & 0.31 & \\
\hline Újkistelekiszőlő & 0.22 & \\
\hline Bokortanyák & 0.19 & \\
\hline Örökösföld & 0.14 & \\
\hline Nyírszőlős & 0.10 & \\
\hline Jósaváros I. & 0.10 & \\
\hline
\end{tabular}




\begin{tabular}{|l|c|l|}
\hline Hímes & 0.05 & \\
\hline Oros & -0.35 & \\
\hline Jósaváros II. & -0.27 & \\
\hline Sóstó & -0.12 & \\
\hline Kertváros & -0.11 & \\
\hline Belváros & -0.06 & \\
\hline Borbánya & -0.05 & \\
\hline
\end{tabular}

3. táblázat - A „,segélypártiság” 2008 (a főkomponens-szkór átlaga). Forrás: saját adatfelvétel.

\begin{tabular}{|l|c|c|}
\hline \multicolumn{2}{|c|}{ A ,csalók a rendszerben” fökomponens átlagai az egyes életkori csoportok esetében } \\
\hline 18-29 év között & -0.10 & $\mathrm{~F}=2.633 ; \mathrm{P}<0.05$ \\
\hline 30-39 év között & -0.03 & \\
\hline 40-49 év között & 0.02 & \\
\hline 50-59 év között & -0.01 & \\
\hline 60-69 év között & -0.01 & \\
\hline 70 év felett & 0.24 & $\mathrm{~F}=6.724 ; \mathrm{P}<0.001$ \\
\hline A ,csalók a rendszerben” fökomponens átlagai az egyes végzettségek tekintetében \\
\hline Alapfokú & 0.16 & \\
\hline Középfokú & 0.02 & \\
\hline Felsőfokú & -0.14 & \\
\hline
\end{tabular}

4. táblázat - A „csalók a rendszerben” főkomponens átlagai 2008 (a főkomponens-szkór átlagai). Forrás: saját adatfelvétel.

A második faktor esetében, azaz annál a véleménycsoportnál, amely a „csalók” jelenlétét vélelmezi a szociális rendszerben, és azt hangsúlyozza, hogy nem igazán azok részesülnek támogatásban, akik rászorulnak, csak két változó esetében találtunk szignifikáns eredményt.

Míg az első faktor esetében az életkor nem volt magyarázó tényező, ebben az esetben igen, különös tekintettel a legidősebbek életkori csoportjára.

Két korcsoport, és különösen a legidősebbek vélik úgy, hogy jellemző a rendszer kihasználása.

A második faktor megítélése hasonló az egyes végzettségek tükrében, mint az első esetében. Ez azt jelenti, hogy az alapfokú, illetve középfokú végzettségüek mindkét nézetet preferálják, azaz szükségesnek tartják a segélyezést, ugyanakkor úgy vélik, hogy a 
rendszert ki is használják olyanok, akik nem lennének jogosultak a támogatásokra. A felsőfokú végzettséggel rendelkezők alapvetően mindkét nézetet elutasítják, azaz a segélyezés jelenlegi rendszerét is elutasítják, de azt is, hogy kihasználható lenne az.

A második faktor esetében más szignifikáns eltérés nem volt megfigyelhető. Ez azt is jelenti, hogy a „csalók a rendszerben” típusú nézetet nem elsődlegesen a demográfiai - társadalmi jellemzők alakítják, annak elutasítása, vagy preferenciája egyéb tényezők függvénye.

Külön csoportot képzett az a markáns vélemény, mely szerint nincs szükség pénzbeli támogatásokra, hasznosabbak lennének a természetbeni segélyek. Ebben az esetben is megvizsgáltuk, hogy milyen demográfiai - társadalmi csoportok preferálták, illetve utasították el az adott véleménycsoport. (5. táblázat)

\begin{tabular}{|l|c|l|}
\hline A „természetbeni juttatások" fökomponens átlagai az egyes végzettségek tekintetében \\
\hline Alapfokú & -0.07 & $\mathrm{~F}=3.301 ; \mathrm{P}<0.001$ \\
\hline Középfokú & -0.02 & \\
\hline Felsőfokú & 0.11 & \\
\hline A „természetbeni juttatások” fökomponens átlagai az egyes jövedelmi decilisekben \\
\hline 1 decilis & -0.22 & $\mathrm{~F}=3.069 ; \mathrm{P}=0.001$ \\
\hline 2 decilis & -0.12 & \\
\hline 3 decilis & 0.02 & \\
\hline 4 decilis & -0.20 & \\
\hline 5 decilis & -0.09 & \\
\hline 6 decilis & 0.10 & \\
\hline 7 decilis & 0.16 & \\
\hline 8 decilis & 0.08 & \\
\hline 9 decilis & 0.16 & \\
\hline 10 decilis & 0.20 & \\
\hline A „természetbeni juttatások” fökomponens átlagai az egyes társadalmi csoportokban \\
\hline Szegények & -0.23 & $\mathrm{~F}=4.259 ; \mathrm{P}<0.05$ \\
\hline Alsó középréteg & -0.09 & \\
\hline Középréteg & 0.03 & \\
\hline Felsö középréteg & 0.14 & \\
\hline Jómódúak & 0.18 & \\
\hline
\end{tabular}


5. táblázat - A „természetbeni juttatások” fökomponens átlagai 2008 (a fökomponens-szkór átlagai). Forrás: saját adatfelvétel.

A harmadik faktor, azaz a természetbeni juttatások preferenciája három változóval mutatott szignifikáns összefüggést. A felsőfokú végzettséggel rendelkezők alapvetően ezt a faktor támogatják, azaz azzal értenének egyet, ha a pénzbeli segélyezést a természetbeni juttatások váltanák fel. Az alacsonyabban iskolázottak azonban ezt elutasítják.

A természetbeni juttatások preferálása a két legalsó decilis, azaz a legszegényebb csoportok körében a legeröteljesebb. Hasonlóan elutasító a 4. és az 5. decilis - azaz az alsó középosztályt alkotó jövedelmi csoport. A tehetősebbek eröteljesen preferálják a természetbeni juttatások dominanciáját. Hasonló eredményre jutunk természetesen, ha az egyes társadalmi rétegek függvényében értelmezzük az adatokat.

A szegények, illetve az alsó középosztály tagjai sokkal inkább segély pártiak, azaz a pénzbeli juttatásokat preferálják (lásd az első faktor átlagait körükben), és elutasítják a természetbeni juttatások dominanciáját. Velük szemben a kedvezőbb helyzetü csoportok inkább a természetbeni juttatásokat preferálják.

A negyedik vélemény szerint csak a valóban rászorulók részesülnek segélyekben azok, akik be is vallják valós anyagi helyzetüket. Ezekben az esetekben a ritkábban adott, de nagyobb összegü segélyek kiosztását preferálták a vélemény támogatói. Érdemes áttekinteni, hogy milyen demográfiai - társadalmi csoportok preferálták, illetve utasították el ezt a véleményt. (6. táblázat)

A negyedik faktor, azaz a rászorultak részesülnek segélyben nézet preferenciái az alábbi változókkal mutatnak összefüggést.

A fiatalok, illetve a középkorosztályúak egyes csoportjai támogatják ezt a véleményt, ugyanakkor a legidősebbek konzekvensek a véleményükben, hiszen miközben úgy vélekednek, hogy csalók vannak a rendszerben, nem is értenek egyet azzal, hogy csak a rászorultak részesülnek támogatásban. A negyedik faktornál hasonlóan vélekednek a 60-69 év közöttiek is.

Az alap-és középfokú végzettséggel rendelkezők következetesen kitartanak amellett, hogy csak a rászorultak kapnak támogatást, illetve az első faktort is figyelembe véve szükség van segélyezésre, lehetőleg nem természetbeni, hanem pénzbeli juttatás formájában. A felsőfokú végzettségüek szintén következetesek, az első faktort is alapjában véve elutasították, így logikus, hogy a negyedikkel sem értenek egyet, egyértelműen a természetbeni juttatásokat preferálják.

Hasonlóak az eredmények, mint az első faktor esetében. A középen lévő csoportok kissé ambivalensek a megítélésben, ugyanakkor mind a legszegényebbek, mind a legtehetősebb csoportok is igen konzekvensek. A leggazdagabbak elutasítják azt a véleményt, hogy csak a rászorultak részesülnének segélyben, nem preferálják a segélyezés jelenlegi rendszerét, illetve elsődlegesen a természetbeni juttatások „hívei”, szemben a legszegényebbekkel, akik nem értenek egyet azzal, hogy feltétlenül a „,csalók” jellemeznék az ellátásokat, valamint a pénzbeli és nem a természetbeni juttatások ,pártfogói”. 
Az elemzést 2010-ben is fökomponens analízissel végeztük, melynek során szintén 4 faktor különült el, a megmagyarázott hányad ebben az esetben is $64,2 \%$. (7. táblázat)

\begin{tabular}{|c|c|c|}
\hline \multicolumn{3}{|c|}{ A ,rászorultak kapnak juttatásokat” fökomponens átlagai az egyes életkori csoportokban } \\
\hline 18-29 év között & 0.14 & $\mathrm{~F}=3.142 ; \mathrm{P}<0.05$ \\
\hline 30-39 év között & -0.02 & \\
\hline 40-49 év között & 0.04 & \\
\hline 50-59 év között & 0.07 & \\
\hline 60-69 év között & -0.16 & \\
\hline 70 év felett & -0.11 & \\
\hline \multicolumn{3}{|c|}{ A „rászorultak kapnak juttatásokat” főkomponens átlagai az egyes végzettségek tekintetében } \\
\hline Alapfokú & 0.01 & $\mathrm{~F}=5.291 ; \mathrm{P}<0.05$ \\
\hline Középfokú & 0.02 & \\
\hline Felsőfokú & -0.09 & \\
\hline \multicolumn{3}{|c|}{ A „rászorultak kapnak juttatásokat” fökomponens átlagai az egyes decilisekben } \\
\hline 1 decilis & 0.25 & $\mathrm{~F}=1.967 ; \mathrm{P}=0.05$ \\
\hline 2 decilis & 0.04 & \\
\hline 3 decilis & -0.10 & \\
\hline 4 decilis & -0.04 & \\
\hline 5 decilis & 0.07 & \\
\hline 6 decilis & 0.06 & \\
\hline 7 decilis & -0.06 & \\
\hline 8 decilis & -0.17 & \\
\hline 9 decilis & -0.16 & \\
\hline 10 decilis & -0.11 & \\
\hline
\end{tabular}

6. táblázat - A „rászorultak kapnak juttatásokat” fơkomponens átlagai 2008 (a fökomponens-szkór átlagai). Forrás: saját adatfelvétel.

Minden valószínűség szerint az általános gazdasági-pénzügyi válság hatására (elbocsátások, devizahitelesek helyzete, reáljövedelem csökkenése, stb.) a vélemények markáns változáson mentek keresztül az elmúlt két évben. A legfontosabb és legjellemzőbb változás két faktor (csalók és természetbeni juttatások preferálása) eltünése, ami természetesen nem jelenti azt, hogy ezek a vélemények nem léteznek, inkább azt, hogy 
a háttérbe szorultak. Alapvetően minden faktor a segélyezés fenntartásáról szól, a rászorultság vált a legerőteljesebbé, a segélypártiak esetében pedig kizárólag finom különbségek mérhetőek: pl. olyan esetekben, hogy gyakrabban kellene kisebb összegeket, vagy ritkábban, nagyobb összegeket adni.

A vélemények átstrukturálódása és általánossá válása azt eredményezte, hogy alig láthatóak különbségek az egyes gazdasági-társadalmi csoportok esetében, amennyiben az egyes faktorok támogatottságát, illetve elutasítását vizsgáljuk. Az alábbiakban csak a szignifikáns eltéréseket mutatjuk be, amelyek mint látható lesz, az esetek többségében a harmadik faktor esetében jellemzőek. (8. táblázat)

\begin{tabular}{|c|c|c|c|}
\hline A rászorultak & Segélypártiak & Segélypártiak II & Segélypártiak III \\
\hline $\begin{array}{l}\text { A segélyeket azok ve- } \\
\text { szik igénybe, akik va- } \\
\text { lóban rászorulnak } \\
(0.710) \text { - Csak azok } \\
\text { részesülnek segély- } \\
\text { ben, akik bevallják va- } \\
\text { lós anyagi helyzetüket } \\
(0.683) \text { - A segélyeket } \\
\text { többnyire azok veszik } \\
\text { igénybe, akik nincse- } \\
\text { nek rászorulva } \\
\text { (-0.729) - Sokan el- } \\
\text { hallgatják valós anya- } \\
\text { gi helyzetüket, a se- } \\
\text { gély megállapítása ér- } \\
\text { dekében } \\
(-0.674)\end{array}$ & $\begin{array}{l}\text { Szükséges a } \\
\text { segélyezés, mert } \\
\text { bizonyos problémákat } \\
\text { csak ezáltal lehet } \\
\text { megoldani }(0.799) \text { - } \\
\text { Inkább pénzbeli } \\
\text { segélyekre lenne } \\
\text { szükség (0.409) - } \\
\text { Nincs szükség } \\
\text { segélyezésre, mert } \\
\text { nem nyújt megoldást } \\
(-0.697)\end{array}$ & $\begin{array}{l}\text { Inkább pénzbeli } \\
\text { segélyekre lenne } \\
\text { szükség }(0.788) \text { - } \\
\text { Ritkábban, de na- } \\
\text { gyobb összegú segé- } \\
\text { lyekre lenne szükség } \\
(0.330) \text { - } \\
\text { Inkább természetbeni } \\
\text { segélyekre lenne szük- } \\
\text { ség }(-0.844)\end{array}$ & $\begin{array}{l}\text { Gyakrabban kellene, } \\
\text { kisebb összegü } \\
\text { segélyeket adni } \\
(0.784) \text { - } \\
\text { Ritkábban, de na- } \\
\text { gyobb összegű segé- } \\
\text { lyekre lenne szükség } \\
(-0.666)\end{array}$ \\
\hline
\end{tabular}

7. táblázat - A segélyezéssel kapcsolatos vélemények főkomponensei, 2010 (rotált faktormátrixok). Forrás: saját adatfelvétel.

\begin{tabular}{|l|c|l|}
\hline 8 általános alatt & 0.393 & $\mathrm{~F}=2.974 ; \mathrm{P}=0.007$ \\
\hline 8 általános & 0.302 & \\
\hline Szakmunkásképző & 0.057 & \\
\hline Szakközépiskola & -0.131 & \\
\hline Gimnázium & 0.032 & \\
\hline Főiskola & -0.041 & \\
\hline Egyetem & -0.200 & \\
\hline
\end{tabular}

8. táblázat - A „segélypártiság” (2. faktor) átlagai az egyes végzettségek tekintetében, 2010 (a fökomponens-szkór átlagai). Forrás: saját adatfelvétel. 
A segélypártiak alapvetően a három legalacsonyabb végzettségủ csoport tagjai közül kerülnek ki, a középfokú végzettséggel rendelkezők megosztottak ebben a tekintetben, míg a diplomások inkább elutasítóak. Hasonló eredményt kapunk a harmadik faktor esetében is. (9. táblázat)

\begin{tabular}{|l|c|l|}
\hline 8 általános alatt & 0.188 & $\mathrm{~F}=4.565 ; \mathrm{P}=0.000$ \\
\hline 8 általános & 0.321 & \\
\hline Szakmunkásképző & 0.155 & \\
\hline Szakközépiskola & 0.021 & \\
\hline Gimnázium & -0.063 & \\
\hline Főiskola & -0.157 & \\
\hline Egyetem & -0.350 & \\
\hline
\end{tabular}

9. táblázat - A ,segélypártiság 2" (3. faktor) átlagai az egyes végzettségek tekintetében, 2010 (a fökomponens-szkór átlagai). Forrás: saját adatfelvétel.

A városlakók ebben az esetben „két pártra szakadtak”, a magasabban kvalifikáltak nem preferálják ezt a faktort. Nem utasítják el a rászorultságot, de nem is preferálják a döntően a pénzbeli segítséget tartalmazó véleményt.

Az egyes társadalmi rétegek esetében csak a harmadik faktor esetében mérhetőek szignifikáns különbségek. (10. táblázat)

\begin{tabular}{|l|c|l|}
\hline Szegények & 0.507 & $\mathrm{~F}=10.637 ; \mathrm{P}=0.000$ \\
\hline Alsó középréteg & 0.131 & \\
\hline Középréteg & -0.094 & \\
\hline Felső középréteg & -0.119 & \\
\hline Jómódúak & -0.546 & \\
\hline
\end{tabular}

10. táblázat - A ,segélypártiság 2" fökomponens átlagai az egyes társadalmi csoportokban, 2010 (a fökomponens-szkór átlagai). Forrás: saját adatfelvétel.

A társadalom legelesettebb rétegei támogatják a faktort, a középrétegtöl fölfelé egyre kevésbé, illetve az elutasítás egyre markánsabb. Ezt erősíti meg az az eredmény, ha ugyanezt az összefüggést a szegények és nem szegények csoportjaiban vizsgáljuk.(11. táblázat)

Érdekes eredmény, hogy ugyan a nem szegények elutasítják ezt a faktort, az elutasítás mértéke sokkal gyengébb, mint a szegények preferenciája. 
Míg korábban az életkor is befolyásoló tényező volt egyes esetekben, 2010-ben ez a változó nem alakította szignifikánsan az eredményeket.

\begin{tabular}{|l|c|l|}
\hline Szegények & 0.335 & $\mathrm{~F}=11.777 ; \mathrm{P}=0.001$ \\
\hline Nem szegények & -0.068 & \\
\hline
\end{tabular}

11. táblázat - A „segélypártiság 2" főkomponens átlagai a szegények és a nem szegények körében, 2010 (a fökomponens-szkór átlagai). Forrás: saját adatfelvétel.

\section{PÉNZBELI ÉS TERMÉSZETBENI ELLÁTÁSOK}

A segélyek tekintetében az elmúlt két évet (2006 és 2007, illetve 2008 és 2009) és a pénzbeli ellátásokat figyelembe véve az alábbi típusok merültek fel a leggyakrabban (az adatok azok százalékában értendőek, akik szociális problémáik megoldása érdekében már igényeltek valamilyen segítséget a Szociális Osztálytól) - 8. ábra.

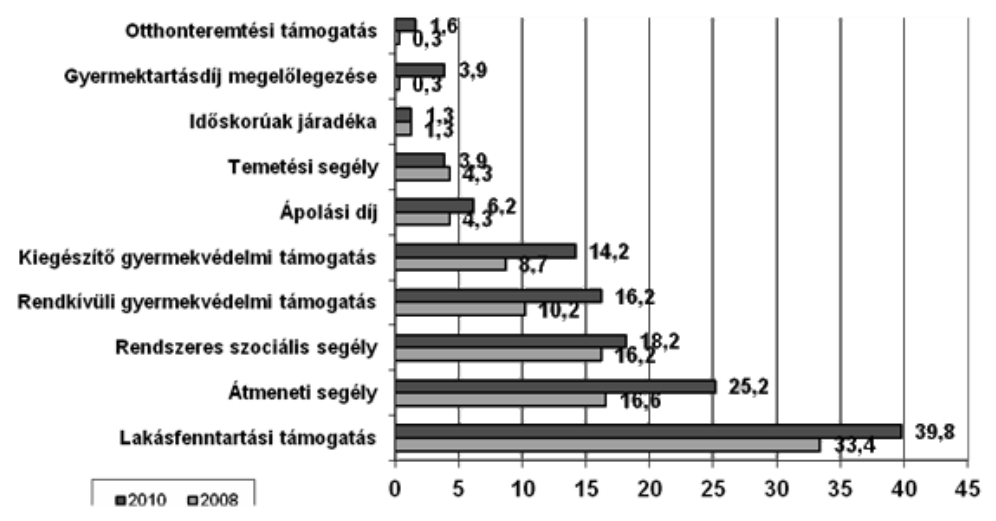

8. ábra - Pénzbeli ellátásokban részesültek aránya, 2008-2010 (\%). Forrás: saját adatfelvétel.

Szinte minden támogatási formában növekedés mérhető, a legjelentősebb arányban a lakásfenntartási támogatás, az átmeneti segély, a rendkívüli gyermekvédelmi támogatás és a kiegészítő gyermekvédelmi támogatás esetében.

A természetben nyújtott ellátások tekintetében a következő sorrendiség, illetve gyakoriság figyelhetö meg -9 . ábra.

Ebben az esetben jelentősebb növekedés a rendszeres gyermekvédelmi kedvezmény esetében mérhető, ami 2008-hoz képest a leggyakoribb támogatási forma lett. Mivel mindkét csoportban három támogatási forma a leggyakoribb, érdemes ezek terü- 
leti, azaz városkörzetekre vonatkozó megoszlását is megvizsgálni. Elsőként a pénzbeli támogatásokat tekintjük át, mivel esetükben néhány forma szignifikáns összefüggést mutat a városkörzetek tekintetében. (10. ábra)



9. ábra - Természetben nyújtott támogatásokban részesültek aránya 2008-2010 (\%). Forrás: saját adatfelvétel.

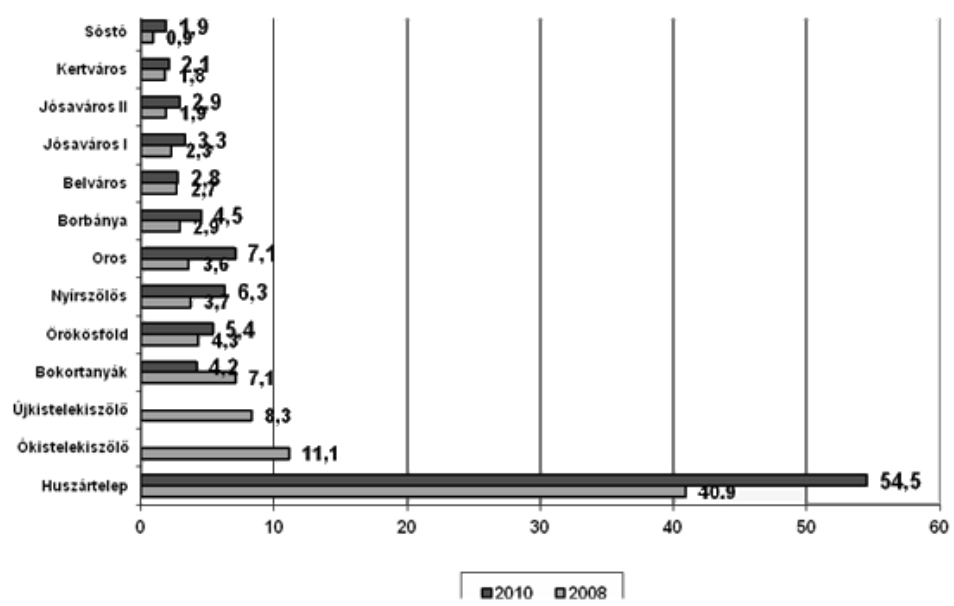

10. ábra - A rendszeres szociális segélyben részesültek megoszlása városkörzetenként (\%). Forrás: saját adatfelvétel.

Egy körzet (Huszártelep) esetében mérhető jelentős növekedés, más esetekben enyhe növekedés, vagy stagnálás figyelhető meg. Érdekes eredmény, hogy miközben 2008ban a lakásfenntartási támogatás szintén szignifikáns eltéréseket mutatott a városkörzetek tekintetében, ez már nem igaz 2010-re. Azt viszont érdemes kiemelni, hogy ebben az esetben is a Huszártelepen mérhető a legmagasabb azoknak az aránya, akik lakásfenntartási támogatásban részesülnek. 
A természetbeni juttatások esetében kettő, a közgyógyellátás, valamint az egészségügyi szolgáltatásra való jogosultság nem mutatott hasonlóan szignifikáns eltéréseket az egyes városkörzetekben, míg a rendszeres gyermekvédelmi kedvezmény igen. (11. ábra).

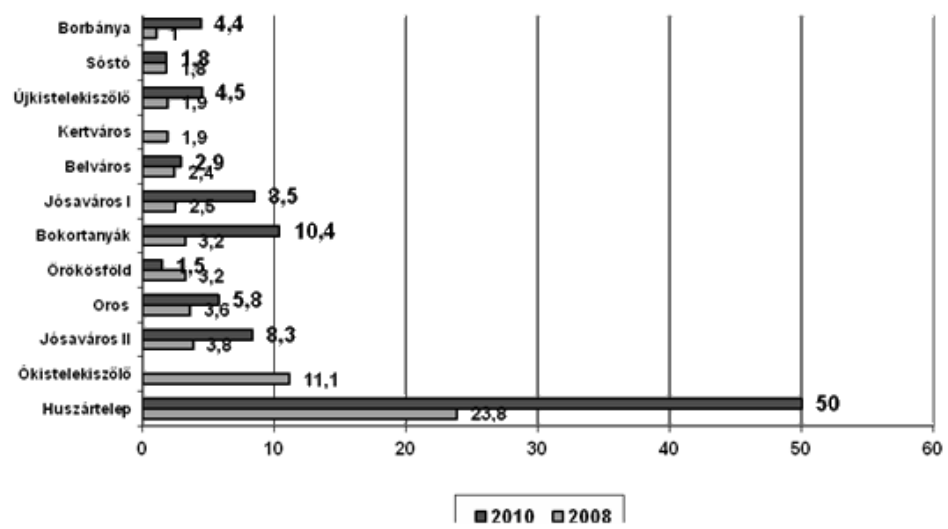

11. ábra - A rendszeres gyermekvédelmi kedvezményben részesültek megoszlása városkörzetenként (\%). Forrás: saját adatfelvétel.

A Huszártelep esetében itt is jelentős mértékü növekedés tapasztalható. Mellette azonban több körzetben mérhető növekedés, ilyen pl. a Jósaváros II, a Bokortanyák, Oros, a Jósaváros I, Borbánya, néhány városkörzet van csak, ahol alig változott az arány.

\section{ÖSSZEFOGLALÁS}

Összefoglalásként megállapíthatjuk, hogy a városlakók bizalma megnövekedett a mesterséges támogató rendszerben „utolsó mentsvárként” tekintenek erre a rendszerre, óriási kihívás elé állítva ezzel a helyi önkormányzatot, elötérbe helyezve az állami szerepvállalás kérdését is. Kiemelt figyelmet érdemel, hogy minden valószínúség szerint az általános gazdaságipénzügyi válság hatására (elbocsátások, devizahitelesek helyzete, reáljövedelem csökkenése, stb.) a segélyezéssel kapcsolatos vélemények markáns változáson mentek keresztül az elmúlt két évben. A lakosok egyre nagyobb csoportja áll a segélyezés mellé, a pénzbeli ellátásokat preferálva. Az ellátásokat tekintve valamennyi segélyezési forma igénybevételénél a vizsgált időszakban - növekedés mérhető. A városban is megfigyelhető az a tendencia, hogy a segélyezett családok aránya - természetes módon - ott magasabb, ahol alacsony a háztartás jövedelme, ahol kevesebb a foglalkoztatott felnőtt és ahol több gyermeket nevelnek. A városban a Huszártelepen jelentős mértékü növekedés tapasztalható a pénzbeli és természetbeni ellátások igénybevételénél. Szalai Júlia ismert szociológus szerint: „A segélyen élők komoly vesztesei lehetnek a válságnak, s nem látszik, hogy bárki védené őket. A romáknál az elkeseredés még nagyobb lehet.” (Szalai, 2008) 


\section{IRODALOM}

1. Bass László - Darvas Ágnes - Dögei Ilona - Ferge Zsuzsa - Tausz Katalin (szerk.)(2007): A szegénység és kirekesztés változása, 20012006. Budapest, MTA GYENP.

2. Filepné Nagy Éva - Fónai Mihály - Fábián Gergely (2006): SzabolcsSzatmár-Bereg megyei népesség szociális helyzete, és egészségügyi állapota In.: Fónai Mihály - Pénzes Mariann - Vitál Attilla (szerk.) Etnikai szegénység, etnikai egészségi állapot? Krúdy - Szocio East Egyesület.

3. Ferge Zsuzsa és Darvas Ágnes (2011): Gyerekesélyek Magyarországon A,,Legyen jobb a gyermeknek!” Nemzeti Stratégia Értékelő Bizottságának 2010. évi jelentése Budapest.

4. Ferge Zsuzsa (2005): What is happenning to poverty? Uncertainties of poverty measures - challenges of ,postmodernity”, Brüsszel, 2005. www.eapn.org.

5. Fónai M - Fábián G - Filepné Nagy É - Pénzes M: Szegénység, egészség és etnicitás: északkelet-magyarországi kutatások empirikus tapasztalatai, Szociológiai Szemle 17: (3-4), pp. 53-84.

6. Gábos András-Szivós Péter (2004.) Szegénység Magyarországon az EU-csatlakozás küszöbén: in: Társadalmi riport 2004, Kolosi Tamás, Tóth István György, Vukovich György (szerk.). Bp: TÁRKI, 96-117.o.

7. Gyorsjelentés a szegényedésről (2000-2003) Szociális Szakmai Szövetség Budapest 2003.

8. Havasi É. (2006.): Megélhetések, anyagi depriváció In.: Szivós Péter-Tóth István György (szerk.) Feketén, fehéren TÁRKI monitor jelentések.

9. Havasi É. (2005.): A transzferjövedelmek szerepe a szegénység csökkentésében. Esély, 2005/4 szám 66-86. o.

10. Monostori Judit (2005.): A jövedelmi szegénység és a segélyezés kapcsolata, KSH, Budéti fogda. Esély, 2005/ 1-2. szám.

11. Nagy Gy. (2008.): Önkormányzati szociális segélyezés, In.: Nagy Gy. (szerk.): Jóléti ellátások, szakképzés és munkakinálat, MTA-KTI.

12. Szalai J. (2007.): Nincs két ország? : társadalmi küzdelmek az állami (túl)elosztásért a rendszerváltás utáni Magyarországon Budapest: Osiris.

13. „Szalai Júlia a kirekesztésről (2008.): A mélyszegénység fennmaradásához komoly érdekek füződnek". 168 óra, 2008. december 25.

14. Tóth István György (2005.): Jövedelemeloszlás. A gazdasági rendszerváltástól az uniós csatlakozásig, Századvég Kiadó. 
